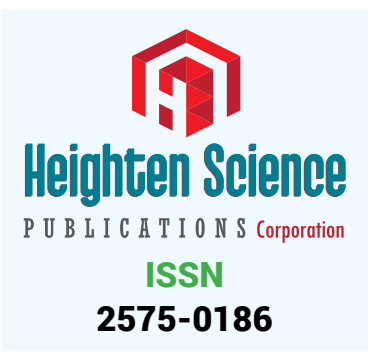

*Address for Correspondence:

Dr. Agoro ES, Department of Biochemistry, Abia state university, Uturu, Abia State, Nigeria, Tel: 08037434995; Email: siragoro@yahoo.com

Submitted: 09 May 2017
Approved: 05 June 2017
Published: 06 June 2017

Copyright: @ 2017 Agoro ES. This is an open access article distributed under the Creative Commons Attribution License, which permits unrestricted use, distribution, and reproduction in any medium, provided the original work is properly cited.

Keywords: Protein profiles; Vitreous humor; Forensic science; Disguised Death (DD); Carbon monoxide Death (CD)

\title{
Comparison of Vitreous Protein Profiles of Rabbits subjected to Acute Carbon Monoxide poisoning and normal animal after death
}

\author{
Agoro ES ${ }^{1 *}$, Akubugwo El ${ }^{1}$, Chinyere $\mathrm{GC}^{1}$ and Samuel $\mathrm{R}^{2}$ \\ 'Department of Biochemistry, Abia state university, Uturu, Abia State, Nigeria \\ ${ }^{2}$ Department of Chemical Pathology, Federal Medical Centre, Yenagoa, Bayelsa State, Nigeria
}

\section{ABSTRACT}

Acute carbon monoxide ( $\mathrm{CO}$ ) poisoning is caused by the inhalation of large quantity of $\mathrm{CO}$ within short time leading to morbidity and mortality. In this study, a total of eighteen (18) rabbits were divided into three (3) groups of six (6) animals each. The first group first group was poisoned with $\mathrm{CO}$ and labelled carbon monoxide death (CD). The second group of animals was killed prior to exposure to $\mathrm{CO}$ and labelled disguised death (DD), while the third was the control group (CG). The vitreous humour samples were collected from all the animals using standard methodologies. The vitreous humour total protein and albumin were estimated while its globulin content and albumin/globulin ratio were derived mathematically. Pearson correlation analyses were used to establish relationships between vitreous protein profile components and the acute graded carbon monoxide concentrations. Results indicated a significant increase $(P<0.05)$ in vitreous total protein and globulin of the studied groups. This observation was more pronounced in the $C D$ group of animals. Therefore the marked elevation of vitreous total protein and globulin may serve as a useful tool in the confirmation of death due to carbon monoxide poisoning.

\section{INTRODUCTION}

Carbon monoxide (CO) is a poisonous, colourless, tasteless, odourless and nonirritant gas [1], produced by incomplete combustion of organic material due to insufficient oxygen supply to enable complete oxidation to carbon dioxide $\left(\mathrm{CO}_{2}\right)$. Carbon monoxide poisoning is the inhalation of large quantity of $\mathrm{CO}$ that is deleterious to the body. This could result to morbidity or mortality based on the concentration of CO inhaled, the health status and age of the victim. Death resulting from CO poisoning is painless and euphoric, hence termed "Angelic Death".

Carbon monoxide poisoning could be intentional, staged managed or accidental. Accidental CO poisoning resulting to death is termed accidental death, whereas intentional and staged managed are termed suicidal and homicidal deaths respectively. However, disguised CO death is believed to be common in the society. Most homicides are now interpreted as suicides due to disguise using CO [2-7]. Such controversial deaths require a scientific proof so as to differentiate true $\mathrm{CO}$ poisoning death from that of disguised.

Carbon monoxide poisoning is responsible for up to 4000 death per year in the United States and is the leading cause of accidental and deliberate poisoning [8]. In Nigeria, data on CO poisoning is sketchy, but reports abound every day.

How to cite this article: Agoro ES, Akubugwo El, Chinyere GC, Samuel R. Comparison of Vitreous Protein Profiles of Rabbits subjected to Acute Carbon Monoxide poisoning and normal animal after death. J Forensic Sci Res. 2017; 1: 040-045. https://doi.org/10.29328/journal.jfsr.1001005 
Postmortem chemistry uses biological fluids and solid tissues for biochemical examination. A sample is classified postmortem if collected after confirmed death [9]. Samples such as blood, sputum, stomach and intestinal fluids, urine, vitreous humour are basic postmortem samples. The choice of vitreous humour is due to its stability, sterility, resistance to putrefaction and mummification. Vitreous humour is a transparent, colourless, gelatinous mass that fills the space between the lens of the eye and the retina lining the back of the eye of humans and other vertebrates. It is also referred to as the vitreous body or simply "the vitreous". It is found at all stages of life as early as during organ formation in the uterus of the woman [10]. Its composition is rarely altered over the course of aging [11]. Also effect of sex or gender on vitreous humour is negligible and of no biochemical effect [11]. Vitreous humour protein profile was utilized for this research. Protein profile is important in the investigation and management of arrays of diseases. Such profiles include total protein, albumin, globulin and albumin/globulin ratio.

Our choice of rabbit is based on their phylogenetical closeness to primates than rodents and offers a more diverse genetic background than inbred and out-bred rodent strains. These facts make the rabbit's model better overall approximate to humans. Lately, rabbit genomics and proteomics are advancing rapidly with several transgenic lines being created and characterized readily available [12]. Furthermore, its big eye afforded added advantage for ease vitreous humour collection with appreciable quantity available.

This research is therefore aimed at utilizing vitreous humour protein profiles to differentiate death due to $\mathrm{CO}$ poisoning from disguised.

\section{MATERIALS AND METHODS}

\section{Study area}

The study was conducted at Igbogene Epie in Bayelsa State of Nigeria. Igbogene Epie is the first community that opens up into the capital City of Yenagoa. Bayelsa state is located within Latitude $4^{0} 15^{1}$ North and Latitude $5^{0}$ and $23^{1}$ South [13]. It is also within longitude $5^{0} 22^{1}$ West and $6^{0} 45^{1}$ East. It is bounded by Delta State on the North, Rivers State on the East and the Atlantic Ocean on the Western and Southern parts. According to the 2006 census figures, Bayelsa has a population of about 1.7 million people [13]. The animal breading and inducement with carbon monoxide was carried out along the Epie Creek section of Igbogene Epie. The vitreous extraction and laboratory analysis were conducted at the Federal Medical Centre Yenagoa.

\section{Study population}

Mead's resource equation was utilized for the calculation of sample size [14]. The equation is: [13] E= N-B-T

Where: $\mathrm{N}$ is the total number of individuals or units in the study (minus 1).

$B$ is the blocking component, representing environmental effects allowed for in the design (minus 1)

$\mathrm{T}$ is the treatment component, corresponding to the number of treatment groups (including control group) being used, or the number of questions being asked (minus 1)

$\mathrm{E}$ is the degrees of freedom of the error component, and should be somewhere between 10 and 20 .

Eighteen (18) rabbits were utilized research as supported by Mead's resource equation. Six (6) rabbits constituted the control group (CG), and treatments one and 
two were made up of six rabbits each. Treatment one was made of rabbit sacrificed before exposure and termed disguised death (DD). Whereas treatment two was made up of rabbits that died as a result of intoxication of maximum carbon monoxide inhalation and termed carbon monoxide death (CD).

Ethical approval: The ethical clearance and experimental protocol were approved by the Ethics Committee of the Bayelsa State Ministry of Health and Animal Welfare Act of 1985 of the United States of America for research and Institutional Animal Care and Use Committee (IACUC) protocol were stringently adhered to.

Selection criteria: Rabbits used were apparently healthy and active as confirmed and approved by a veterinary doctor. Rabbits showing signs and symptoms of illness were excluded from the research. Also excluded were rabbits with any form of derangements. The research utilized only male albino rabbits of same age and weight. The age range was between six to eight months. The weight brackets were $1.5-2 \mathrm{~kg}$. Turbid vitreous humours were rejected.

\section{Collection of sample}

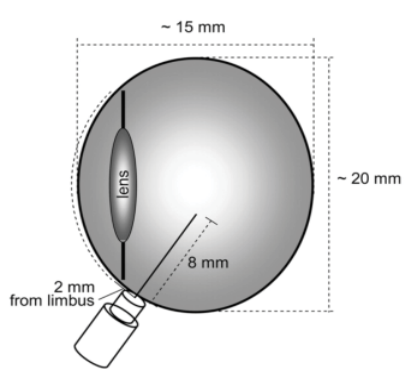

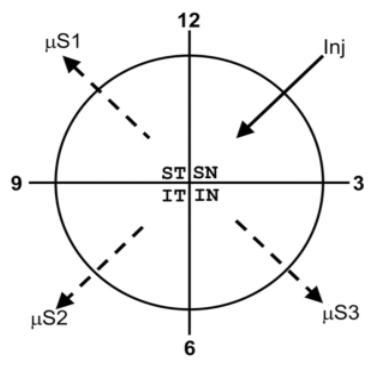

OD

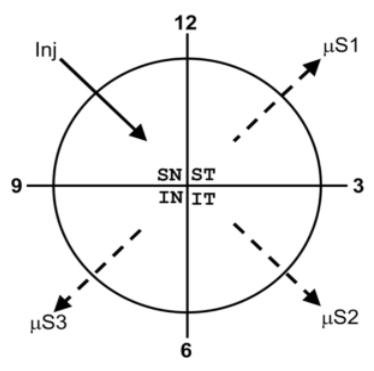

os

\section{Courtesy; Tente et al., [14]}

The vitreous humor samples were collected by the method of Coe [15]. Briefly, using a $10 \mathrm{~mL}$ syringe and a needle, a scleral puncture was made on the lateral canthus and the total extractable vitreous humor was aspirated from the eye. Adequate care was taken to gently aspirate the fluid to avoid tearing of any loose tissue fragments surrounding the vitreous chamber. On an average $1.0 \mathrm{~mL}$ vitreous humor was collected from each rabbit eye. Only crystal clear liquids free of tissue contaminants and fragments were used in the study.

Immediately after sample collection in each case, the vitreous humour was transferred into plain containers for the protein profile assay [16]. Prior to analysis the vitreous samples were centrifuged at $2050 \mathrm{~g}$ for $10 \mathrm{~min}$. The supernatants were separated and used for the analysis.

\section{Determination of vitreous protein profiles}

Vitreous total protein was estimated quantitatively using Biuret Method as modified by Randox Laboratories (United Kingdom) (Randox kit leaflet). Biuret method is the most widely used method for protein analysis in body fluids [17] and one recommended by the International Federation of Clinical Chemistry (IFCC) expert panel for the determination of total protein (Randox kit leaflet). Viterous albumin was estimated quantitatively using Bromocresol Green Method as modified by Randox Laboratories (United Kingdom) (Randox kit leaflet). Vitreous globulin concentration was derived by subtracting vitreous albumin from vitreous total protein. The value is an estimate of serum globulin [20].

Total Protein= Albumin+Globulin

Hence, Globulin= Total Protein-Albumin. 
Albumin/globulin ratio was also gotten mathematically by dividing the concentration of albumin by that of globulin.

\section{Determination of carbon monoxide concentrations}

The concentration of CO was extrapolated from the findings of Golden [19,20], in averring CO concentrations (ppm) that can lead to death and its corresponding carboxyhaemoglobin.

\section{Statistical Analyses}

Data were analyzed with Statistical Package for Social Sciences (SPSS) program (SPSS Inc., Chicago, IL, USA; Version 18-21) and Microsoft excel. Pearson correlation analyses were used to establish relationships between vitreous protein profile components and the acute graded carbon monoxide concentrations. Also, one-way ANOVA (Post Hoc- LSD) was used in comparing the means of the protein profile parameters of the study groups.

\section{DISCUSSION}

Acute carbon monoxide poisoning is the inhalation of large quantity or concentration of $\mathrm{CO}$ within short period. The effect could result to morbidity or mortality based on the severity and duration. The vitreous protein profiles analyzed include total protein, albumin, globulins and albumin/globulin ratio $(\mathrm{A} / \mathrm{G})$ (Table 1). The study showed that there was a significant increase $(\mathrm{P}<0.05)$ in concentrations of vitreous total proteins and globulin in the studied groups, though markedly higher in the CD group, contrarily, vitreous albumin and $A / G$ ratio exhibited no significant difference $(P>0.05)$. However, Pearson correlation showed no significant relationships $(P>0.05)$ between acute graded $\mathrm{CO}$ and the $\mathrm{DD}$ and the $\mathrm{CD}$ (Table 2).

Vitreous total protein increase in both the DD and CD is characteristic of postmortem change $[10,21]$. However death resulting from $C D$ has a higher concentration of vitreous total proteins as against DD $(\mathrm{P}<0.05)$. The markedly increase is based on the leap in vitreous globulin concentration (Table 3). Globulin is an immune-protein crucial for antibodies and immunoglobulin production [22]. Globulins are massively produced due to invasion of the body by foreign bodies, inflammations or infections. Carbon

Table 1: The Mean Concentrations of the Various Postmortem Vitreous Humour Biochemical Parameters Exposed to Acute Graded CO.

\begin{tabular}{|c|c|c|c|}
\hline $\begin{array}{l}\text { Parameters } \\
\text { Measured }\end{array}$ & $\begin{array}{c}\text { Control } \\
\text { Concentration } \\
\text { (Mean } \pm S D)\end{array}$ & $\begin{array}{c}\text { DD } \\
\text { Concentration } \\
\text { (Mean } \pm S D)\end{array}$ & $\begin{array}{c}\text { CD } \\
\text { Concentration } \\
\text { (Mean } \pm S D)\end{array}$ \\
\hline CO (ppm) & $0 \pm 0$ & $6000 \pm 4953$ & $6000 \pm 4953$ \\
\hline Total Protein $(\mathrm{g} / \mathrm{l})$ & $4.3 \pm 2.5$ & $14.8 \pm 1.7$ & $18.2 \pm 2.6$ \\
\hline Albumin (g/l) & $0.75 \pm 0.5$ & $1.3 \pm 1.2$ & $1.0 \pm 0.8$ \\
\hline Globulin (g/l) & $3.5 \pm 3.0$ & $13.5 \pm 2.1$ & $17.3 \pm 3.2$ \\
\hline A/G Ratio & $0.21 \pm 0.18$ & $0.10 \pm 0.05$ & $0.06 \pm 0.04$ \\
\hline
\end{tabular}

Key: $\mathrm{DD}=$ Disguised death, $\mathrm{CD}=$ carbon monoxide death, Values expressed above are mean of determinations. \pm standard deviation (SD)

Table 2: The Observed Pearson's Correlation Coefficient between Graded Carbon Monoxide Concentrations and Studied Vitreous Postmortem Biochemical Parameters for the DD Group.

\begin{tabular}{|c|c|c|}
\hline $\begin{array}{c}\text { Parameters } \\
\text { Measured }\end{array}$ & $\mathbf{r}(\mathbf{D D})$ & $\mathbf{r}(\mathbf{C D})$ \\
\hline Total Protein (g/l) & $-0.772(0.228)$ & $0.092(0.908)$ \\
\hline Albumin (g/l) & $-0.321(0.679)$ & $-0.908(0.736)$ \\
\hline Globulin (g/l) & $-0.440(0.560)$ & $0.143(0.857)$ \\
\hline A/G Ratio & $0.211(0.789)$ & $-0.334(0.666)$ \\
\hline $\begin{array}{l}\text { Key: DD=Disguised Death, CD }=\text { Carbon monoxide Death, } r=\text { Pearson coefficient. } \\
\text { * significance } P<0.05\end{array}$ \\
\hline
\end{tabular}


Table 3: A Multiple Comparisons of Postmortem Vitreous Protein Profiles on the basis of Levels of Acute CO Intoxications.

\begin{tabular}{|c|c|c|c|c|}
\hline Categories & TP & ALB & GLO & A/G Ratio \\
\hline CG & $4.3 \pm 2.5$ & $0.75 \pm 0.5$ & $3.5 \pm 3.0$ & $0.21 \pm 0.18$ \\
\hline DD & $14.8 \pm 1.7$ & $1.3 \pm 1.2$ & $13.5 \pm 2.1$ & $0.10 \pm 0.05$ \\
\hline CD & $18.2 \pm 2.6$ & $1.0 \pm 0.8$ & $17.3 \pm 3.2$ & $0.06 \pm 0.04$ \\
\hline F-value & 39.61 & 0.677 & 24.80 & 1.06 \\
\hline $\mathbf{P}$ & 0.00 & 0.532 & 0.000 & 0.390 \\
\hline \multicolumn{5}{|c|}{ POST HOC (LSD) } \\
\hline CG Vs DD & 0.00 * & 0.283 & 0.001 * & 0.274 \\
\hline CG Vs CD & 0.00 * & 0.466 & 0.000 * & 0.213 \\
\hline DD Vs CD & 0.06 & 0.712 & 0.091 & 0.865 \\
\hline \multicolumn{5}{|c|}{$\begin{array}{l}\text { Keys: } C G=\text { Controls, } D D=\text { Disguised Death, } C D=\text { Carbon mo } \\
\text { Globulin, } A / G=\text { Albumin/Globulin Ratio, } L S D=L \text { east Significar } \\
\text { Values are mean of determination } \pm \text { standard deviation }(S D) \\
\text { *represents significant at } 0.05 \text { Confidence }(P<0.05)\end{array}$} \\
\hline
\end{tabular}

monoxide accesses to body stimulate inflammatory reactions that lead to production of globulins so as to protect the body from harm. Hence the observed increase in vitreous globulins among the CD group is attributable to the body intention to wade off the unfriendly environment occasioned by increased concentration of $\mathrm{CO}$.

Similar to results obtained by other workers, this research attests to presence of total proteins, albumin and globulins in the vitreous but at very low concentrations compared to that of plasma as applicable to humans $[9,11,23]$. The plausible reason is that portal of entry of protein to the vitreous is very difficult as occasioned by the charge balance between the interior and the exterior [23]. The tight junctional complexes within the retinal vascular endothelium of the eye inhibit passage of high molecular weight constituents (10). Also, the basal lamina of the vitreo-retinal junction physically blocks the passage of large molecules. These factors are believed to contribute to the difficulty of albumin and other proteins crossing the vitreous barriers. In addition to the vitreo-retinal barrier, two other important factors also prevent the vitreous constitutes to equilibrate with blood and the surrounding fluids. These are: active transport pumping mechanism located at the level of ciliary epithelium, retinal vascular epithelium and retinal pigment epithelium and small surface area to volume ratio of the vitreous [21].

\section{CONCLUSION}

This research has brought to bear a hallmark of markedly elevated vitreous total protein and globulin occasioned by $\mathrm{CO}$ death. Hence, forensic experts should factor vitreous protein profiles as part of strings of analysis carried out in investigation of crimes related to $\mathrm{CO}$ poisoning. Also, vitreous protein profile should be introduced as routine investigation in autopsy protocol especially in CO related deaths. There is need to determine the components of the globulin that led to the observed elevation. It is also important to transpose the findings obtained here to humans in cases of $\mathrm{CO}$ poisoning.

\section{REFERENCES}

1. Nageshkumar GR. Cardiac Poisons "In Textbook of Forensic Medicine and Toxicology". Jaypee Brothers. 2006; 425-432. Ref.: https://goo.gl/4IL1Ap

2. Camps FE. Carbon monoxide poisoning accident, suicide and murder. Med Leg J. 1950; 18: 75-85. Ref.: https://goo.gl/iVwg6Y

3. Akaishi S, Oshida S, Hiraiwa K, Sebetan IM, Ohno Y, et al. Homicide and camouflaged carbon monoxide poisoning in Japan. Z Rechtsmed. 1982; 88: 298-304. Ref.: https://goo.gl/c4iZ66

4. Patel P, Scattler S. The Case Files: Carbon Monoxide Intoxication Disguised as Atrial Fibrillation. Emergency Medicine News. 2013; 35: 6. Ref.: https://goo.gl/3o1CNR 
5. Mohammed A, Osama A, Maram A. Carbon monoxide toxicity in Dammam, KSA: Retrospective study. Egyptian Journal of Forensic Sciences. 2015; 5: 36-38. Ref.: https://goo.gl/zTz83q

6. Feng L, Heng C, Sihai L, Haipeng J, Hongjun L, et al. Carbon monoxide poisoning as a cause of death in Wuhan, China: A retrospective six-year epidemiological study (2009-2014). Forensic Science International. 2015; 253: 112-118. Ref.: https://goo.gl/m0StXE

7. San Juan County. Cause of two Islanders death comfirmed of carbon monoxide poisoning. Journal of the San Juan Islands. 2017. Ref.: https://goo.gl/u1Fa0d

8. Michael L. "Toxicology" In Laboratory Medicine: The Diagnosis of Disease in the Clinical Laboratory. First edititon. Mc Graw Hill LANGE. 2010; 167. Ref.: https://goo.gl/hEhDSx

9. Agoro ES, Okoye FBC, Azuonwu O, Ebiere NE. Extrapolation of Three Hourly Post-Mortem Interval using some Vitreous Chemistry Parameters. J Forensic Res. 2017; 8: 1-5. Ref.: https://goo.gl/OfOuaO

10. Agoro ES, Okoye FBC, Azuonwu O, Ebiere NE. The Effect of Age and Sex on Vitreous Humour Chemistry and Postmortem Interval (PMI). sss. 2017B; 6058.

11. Bosze Z, Houdebine LM. Application of rabbits in biomedical research: a review. World Rabbit Sci. 2006; 14: 1-14. Ref.: https://goo.gl/KBwesC

12. Alagoa EJ. The land and people of Bayelsa State: Central Niger Delta. Onyoma Research Publication. 2009. Ref.: https://goo.gl/KsD86z

13. Kirkwood J, Robert H. The UFAW Handbook on the Care and Management of Laboratory and Other Research Animals. Wiley-Blackwell. 2010; 29. Ref.: https://goo.gl/ErvSeg

14. Tente W, O'Rourke P, Sherman S, Kauper K, McGovern C, et al. Sustained Delivery of hCNTF to Rabbit Vitreous Humour by Two Polymer Encapsulated Cell Lines in the NT-502 Device. IO VS. 2004; 45. Ref.: https://goo.gl/fZTUdE

15. Coe Jl. Vitreous potassium as a measure of the postmortem interval: an historical review and critical evaluation. Forensic Science International. 1989; 42: 201-213. Ref.: https://goo.gl/o15BW3

16. Peter TJ. Proposals for standardization of total serum protein assay. Clin Chem. 1968; 14: 11471159. Ref.: https://goo.gl/OC3KI1

17. Michael LB, Janet LD, Edward PF. Amino Acids and Proteins. New York, $2^{\text {nd }}$ edition, J.B. Lippincott Company. 1992.

18. Jakobiec A Frederick. Age related changes in vitreous structure, Principles and practice of ophthalmology $2^{\text {nd }}$ edition. 2009; 1792-95.

19. Goldstein M. Carbon monoxide poisoning. J Emergency Nursing. 2008; 34: 538-542. Ref.: https://goo.gl/pkicih

20. Struttmann T, Scheerer A, Prince TS, Golden LA. Unintentional Carbon Monoxide Poisoning from an unlikely source. JABFM. 1998; 11: 481-484. Ref.: https://goo.gl/2HL2AT

21. Amith Mulla. Role of vitreous humour biochemistry in forensic pathology. University of Saskatchewan. 2005. Ref.: https://goo.gl/bbxmj4

22. Loh RK, Vale S, McLean-Tooke A. Quantitative serum innunoglobin tests. Aust Fam Physician. 2013; 42: 195-198. Ref.: https://goo.gl/4LGy1b

23. Hawkins KN. Contribution of plasma proteins to the vitreous of the rat. Curr Eye Res. 1986; 5: 655 663. Ref.: https://goo.gl/MXDNEV 